LUZ, JMQ; OLIVEIRA, RC; LANA, RMQ; SILVA, JRR; REBOUÇAS, TNH. 2020. Potassium chloride fertilization of potatoes: nutrient uptake rate and tuber yield of cultivars Ágata and Atlantic. Horticultura Brasileira 38: 400-406. Doi: http://dx.doi.org/10.1590/s0102-0536202004010

\title{
Potassium chloride fertilization of potatoes: nutrient uptake rate and tuber yield of cultivars Ágata and Atlantic
}

\author{
José Magno Q Luz ${ }^{1} \mathbb{D}$; Roberta C Oliveira ${ }^{1} \mathbb{D}$; Regina Maria Q Lana ${ }^{1} \mathbb{D}$; João Ricardo R Silva ${ }^{1} \mathbb{D}$; Tiyoko \\ Nair H Rebouças ${ }^{2} \mathbb{D}$
}

${ }^{1}$ Universidade Federal de Uberlândia (UFU), Uberlândia-MG, Brasil; jmagno@ufu.br (author for correspondence); robertacamargoss@ gmail.com; rmqlana@hotmail.com; joaoragr@hotmail.com; ${ }^{2}$ Universidade Estadual do Sudoeste da Bahia (UESB), Vitória da ConquistaBA, Brasil; tiyoko@uesb.edu.br

\begin{abstract}
Potassium $(\mathrm{K})$ is the nutrient taken up in the greatest quantity by the potato plant. Obtaining information about the relationship between tuber yield and $\mathrm{K}$ application rate allows improvements in fertilizer use efficiency. We aimed to evaluate the variation in potassium fertilizer doses in uptake rate of other nutrients and in potato tuber yield. The experiments were carried out in Unaí-MG testing cultivars Ágata and Atlantic and in Mucugê-BA evaluating cultivar Ágata. The experimental design used was randomized blocks. We studied the rates of $0 ; 70 ; 110 ; 220$, and $450 \mathrm{~kg} \mathrm{ha}^{-1} \mathrm{~K}_{2} \mathrm{O}$. The increase in $\mathrm{K}$ rate reduced the levels of $\mathrm{S}, \mathrm{Ca}, \mathrm{Mg}$ and $\mathrm{B}$ in Atlantic-Unaí, $\mathrm{Ca}, \mathrm{Mg}, \mathrm{Zn}$ and B in Ágata-Unaí and S, Fe and B in Ágata-Mucugê. The cultivar Atlantic-Unaí did not respond to the increase of potassium fertilizer dose, with a total of 32.3 to $37 \mathrm{t} \mathrm{ha}^{-1}$. Cultivars Ágata-Unaí and ÁgataMucugê responded to rates estimated at 225 and $166 \mathrm{~kg} \mathrm{ha}^{-1} \mathrm{~K}_{2} \mathrm{O}$ with the highest productivities of 53.9 and $56.2 \mathrm{t} \mathrm{ha}^{-1}$, respectively.
\end{abstract}

Keywords: Solanum tuberosum, mineral fertilization, plant nutrition.

\section{RESUMO}

Adubação em batata com cloreto de potássio: taxa de absorção de nutrientes e produtividade de tubérculos de Ágata e Atlantic

O potássio $(\mathrm{K})$ é o nutriente mais absorvido pela batateira. Conhecer a relação entre a produção e a taxa de $\mathrm{K}$ aplicada permite melhorar o uso de fertilizantes. Objetivou-se avaliar a variação de doses de fertilizante potássico na taxa de absorção de outros nutrientes e na produtividade de tubérculos de batata. Os experimentos foram conduzidos em Unaí-MG com as cultivares Ágata e Atlantic e em Mucugê-BA com Ágata. O delineamento utilizado foi de blocos ao acaso. Foram avaliadas as doses $0 ; 70 ; 110 ; 220$ e $450 \mathrm{~kg} \mathrm{ha}^{-1} \mathrm{de}$ $\mathrm{K}_{2} \mathrm{O}$. O aumento da dose de $\mathrm{K}$ reduziu os teores de $\mathrm{S}, \mathrm{Ca}, \mathrm{Mg}$ e B em Atlantic-Unaí, Ca, Mg, Zn e B em Ágata-Unaí e S, Fe e B em Ágata-Mucugê. A cultivar Atlantic-Unaí não respondeu ao aumento da adubação potássica, com produtividade total entre 32,3 e 37 tha $^{-1}$. A cultivar Ágata-Unaí e Ágata-Mucugê responderam até as doses estimadas de 225 e $166 \mathrm{~kg} \mathrm{ha}^{-1}$ de $\mathrm{K}_{2} \mathrm{O}$ com produtividades máximas de 53,9 e $56,2 \mathrm{t} \mathrm{ha}^{-1}$, respectivamente.

Palavras-chave: Solanum tuberosum, fertilização mineral, nutrição de plantas.

\section{Received on May 26, 2020; accepted on October 27, 2020}

$\mathrm{P}$ tatoes are highly nutrientdemanding plants, and potassium $(\mathrm{K})$ is the nutrient which is taken up in the greatest quantity (Job et al., 2019). Potassium increases plant height and crop vigor, playing an important role in translocating carbohydrates from the leaves to roots (Jasim et al., 2013). Potassium-deficient soil can significantly cause damage to potato crop (Pervez et al., 2013).

Potato cultivars behave differently in relation to potassium demand, according to its yield potential and number of tubers. Therefore, besides having reliable information on soil components, the nutrient dose should meet the needs of each cultivar (Bansal \& Trehan, 2011).

In Brazil, the lack of studies on the nutrient-use efficiency in crops, in different soils and states, makes the producers use fertilization in amounts greater than required: it increases crop production costs and reduces the fertilizer-use efficiency (Fernandes \& Soratto, 2013).

Thus, studies on the main cultivars used in Brazil should be stimulated, aiming to provide information on the dynamics of nutrients. The results help prevent producers to follow standardized recommendations and luxury consumption of $\mathrm{K}$ by the potato crop, as well as optimize productivity and fertilizer use in agriculture (Silva \& Fontes, 2016).

In literature, potato crop responded to doses from 150 to $400 \mathrm{~kg} \mathrm{ha}^{-1} \mathrm{~K}_{2} \mathrm{O}$, considering the highest doses related to low availability in soil, as well as the highest clay contents (Silva \& Fontes, 2016; Zelelew et al., 2016). According to Zörb et al. (2014), prioritizing K fertilization is necessary to overcome soil fertility decline and improve productivity, guaranteeing food safety. Relationship between productivity and soil exchangeable $\mathrm{K}$ content allows to determine critical $\mathrm{K}$ value, below or above which different $\mathrm{K}$ fertilization 
strategies can be adopted (Sandaña et al., 2020), so that they maximize resource savings and ensure greater profitability through satisfactory and quality production. Thus, the aim of this study was to evaluate the influence of potassium chloride doses on nutrient uptake rate and on the tuber yield of potato cultivars Ágata and Atlantic.

\section{MATERIAL AND METHODS}

\section{Location and installation}

The experiments were installed in potato-producing rural properties in the municipality of Unaí-MG and MucugêBA, using cultivars Ágata and Atlantic, and cultivar Ágata, respectively.

In Unaí-MG $\left(16^{\circ} 21 ' 27\right.$ 'S, $46^{\circ} 54^{\prime} 22^{\prime \prime} \mathrm{W}, 640 \mathrm{~m}$ altitude), Ágata and Atlantic were grown from May to August and from June to September, 2014, in a clay-texture soil, classified as typic distrophic Red Latosol. The local climate is Awi according to Köppen. Total rainfall of 50 and 57 $\mathrm{mm}$ from May to August and June to September, respectively. Maximum and minimum temperature from May to August ranged from 29 to $37^{\circ} \mathrm{C}$ and 9 to $14^{\circ} \mathrm{C}$, respectively, and from June to September, 2014, from 29 to $40^{\circ} \mathrm{C}$ and 9 to $17^{\circ} \mathrm{C}$, respectively. Relative humidity ranged from 51 to $68 \%$ and 52 to $64 \%$ from May to August and from June to September, respectively.

In Mucugê-BA $\left(13^{\circ} 00^{\prime} 19^{\prime}\right.$ 'S, $41^{\circ} 22^{\prime} 15^{\prime \prime} \mathrm{W}, 986 \mathrm{~m}$ altitude), the growing season was from September to December, 2014. The local climate is $\mathrm{Cfb}$ according to Köppen, maximum and minimum temperature ranged from 25 to $29^{\circ} \mathrm{C}$ and 12 to $16^{\circ} \mathrm{C}$, respectively. Relative humidity ranged from 62 to $80 \%$ and total rainfall was $350 \mathrm{~mm}$. The soil in the experimental area is medium texture and classified as Red-Yellow Latosol (Embrapa, 2017).

Soil chemical analysis of this area was performed before planting, in the 0-20 cm layer, according to the method described by Embrapa (2017). Chemical characterization of the soils was: ÁgataMucugê: $\mathrm{pH}\left(\mathrm{H}_{2} \mathrm{O}\right)=5.7$; $\mathrm{P}($ Mehlich $)=$ $11.7 \mathrm{mg} \mathrm{dm}^{-3} ; \mathrm{K}=84 \mathrm{mg} \mathrm{dm}^{-3} ; \mathrm{Ca}=1.3$ $\mathrm{cmol}_{\mathrm{c}} \mathrm{dm}^{-3} ; \mathrm{Mg}=0.4 \mathrm{cmol}_{\mathrm{c}} \mathrm{dm}^{-3} ; \mathrm{H}+\mathrm{Al}$ $=1.8 \mathrm{cmol} \mathrm{dm}^{-3} ; \mathrm{CTC}=3.7 \mathrm{cmol} \mathrm{dm}^{-3}$ and $\mathrm{V}=51.9 \%$; Ágata-Unaí: $\mathrm{pH}(\stackrel{\mathrm{c}}{\mathrm{H}} \mathrm{O})$ $=5.2 ; \mathrm{P}($ Mehlich $)=14.5 \mathrm{mg} \mathrm{dm}^{-3} ; \mathrm{K}$ $=84.4 \mathrm{mg} \mathrm{dm}^{-3} ; \mathrm{Ca}=2.9 \mathrm{cmol}_{\mathrm{c}} \mathrm{dm}^{-3}$; $\mathrm{Mg}=1.1 \mathrm{cmol}_{\mathrm{c}} \mathrm{dm}^{-3} ; \mathrm{H}+\mathrm{Al}=3.5 \mathrm{cmol}_{\mathrm{c}}$ $\mathrm{dm}^{-3} ; \mathrm{CTC}=7.7 \mathrm{cmol}_{\mathrm{c}} \mathrm{dm}^{-3}$ and $\mathrm{V} \stackrel{\mathrm{c}}{=}$ $54.6 \%$ and Atlantic-Unaí: $\mathrm{pH}\left(\mathrm{H}_{2} \mathrm{O}\right)=$ 5.3; $\mathrm{P}($ Mehlich $)=17 \mathrm{mg} \mathrm{dm}^{-3} ; \mathrm{K}=89$ $\mathrm{mg} \mathrm{dm}{ }^{-3} ; \mathrm{Ca}=3.2 \mathrm{cmol}_{\mathrm{c}} \mathrm{dm}^{-3} ; \mathrm{Mg}=0.9$ $\mathrm{cmol}_{\mathrm{c}} \mathrm{dm}^{-3} ; \mathrm{H}+\mathrm{Al}=3.6 \mathrm{cmol} \mathrm{dm}^{-3} ; \mathrm{CTC}$ $=7.9 \mathrm{cmol}_{\mathrm{c}} \mathrm{dm}^{-3}$ and $\mathrm{V}=54.4 \%$.

For each cultivar and location, we evaluated the effect of potassium dose $\left(0,70,110,220\right.$ and $\left.450 \mathrm{~kg} \mathrm{ha}^{-1} \mathrm{~K}_{2} \mathrm{O}\right)$. The standard dose of $\mathrm{N}$ and $\mathrm{P}$ fixed in $120 \mathrm{~kg} \mathrm{ha}^{-1} \mathrm{~N}$ and $480 \mathrm{~kg} \mathrm{ha}^{-1} \mathrm{P}_{2} \mathrm{O}_{5}$, followed the recommendations of Soil Fertility Commission of Minas Gerais (Comissão de Fertilidade dos Solos de Minas Gerais) (CFSEMG, 1999). Sources of N, P and K used were urea, triple superphosphate and potassium chloride, respectively. At planting, the following micronutrients were applied: $2.2 \mathrm{~kg} \mathrm{ha}^{-1}$ boron and copper and $5.4 \mathrm{~kg}$ ha $^{-1}$ manganese and zinc in Unaí-MG and $2.5 \mathrm{~kg} \mathrm{ha}^{-1}$ boron, copper and zinc and $5 \mathrm{~kg} \mathrm{ha}^{-1}$ manganese in Mucugê-BA.

\section{Experimental design}

The experimental arrangement was in randomized blocks, with four replicates. Each plot consisted of six $6-\mathrm{m}$ long rows, spaced $0.8 \mathrm{~m}$ between rows and $0.3 \mathrm{~m}$ between plants, totalizing a total area of $28.8 \mathrm{~m}^{2}$ per plot. Evaluations were done in two central rows, in the useful area of the plot, totalizing $8 \mathrm{~m}^{2}$; the other plants formed the plot border.

\section{Installation and conduction of the experiment}

Maize had previously been grown in the experimental areas. Three months before planting, liming was performed. We used dolomitic limestone (PRNT: $90 \%$ ) at a dose of 1 and 0.9 tha $^{-1}$ in ÁgataUnaí and Atlantic-Unaí, respectively, and $0.6 \mathrm{t} \mathrm{ha}^{-1}$ in Ágata-Mucugê. After preparing, plowing and harrowing the soil, furrows were opened. Nutrient doses were distributed into planting furrows manually, being incorporated using a hoe. In the three experiments, of the total $\mathrm{N}$ and $\mathrm{K}$ applied, $60 \%$ were distributed at planting, and the other
$40 \%$ in mulching, 27 days after planting (DAP) when hilling up was performed. The total dose of $\mathrm{P}$ was distributed at planting.

In these experiments, potato plants were grown under center-pivot irrigation, supplied with sufficient water for the full development of the crop (500 $-550 \mathrm{~mm}$ ) throughout the cultivation period. Generally, a 6-mm water depth was applied in both areas, every 2 days, from emergence to hilling up, $10 \mathrm{~mm}$ during vegetative development and 12 $\mathrm{mm}$, every 3 days, in stolonization and tuberization phases.

According to monitoring of pests, diseases and weeds, products registered for potato cultivation were applied, when necessary, following the recommended doses (Lopes et al., 2016; Nava \& DiezRodríguez, 2016; Silva, 2016).

\section{Evaluated traits}

\section{Macro and micronutrient contents in leaves}

In each place and cultivar, at 35 days after planting (DAP), 20 expanded leaves from the third fully developed trefoil of each plot were collected (CFSEMG, 1999). The leaves were kept in paper bags and sent to Safrar agricultural laboratory (laboratory of agricultural analyses) in order to quantify the nutrients.

The sampled leaves were washed according to the methodology of Bataglia et al. (1983). In order to quantify dry mass, fresh vegetables were placed in an oven with forced air circulation at $65^{\circ} \mathrm{C}$. After that, the leaves were ground and the macronutrient contents in leaves were determined: nitrogen, phosphorus, potassium, calcium, magnesium, sulfur and the micronutrients: boron, copper, iron, manganese and zinc (Embrapa, 1997).

\section{Productivity and quality of tubers}

At 90 DAP, desiccation in experiments with Agata cultivar was carried out using $2.5 \mathrm{~L} \mathrm{ha}^{-1}$ herbicide diquat (500 $\left.\mathrm{g}_{\mathrm{ia} \mathrm{ha}}{ }^{-1}\right)$. In the experiment with Atlantic, no desiccation was done. At the end of the experiments (112 and 115 DAP for Ágata-Unaí and AtlanticUnaí and 106 DAP for Ágata-Mucugê), the tubers in the useful area of the plots 
were manually collected (discarding 0.5 $m$ of the end of each row), classified and weighed using an electronic scale. The obtained values were transformed in $\mathrm{tha}^{-1}$.

Classification was carried out according to the Ministerial Order No. 69, of February 23, 1995, by the Ministry of Agriculture, Livestock and Food Supply (MAPA); the tubers were classified according to the diameter: special ( $>45 \mathrm{~mm}$ ), commercial (greater than or equal to $33 \mathrm{~mm}$ and less than $45 \mathrm{~mm}$ ) and non-standard (less than $33 \mathrm{~mm}$ ). The sum of the classifications constituted the total productivity.

\section{Statistical analysis}

Obtained data were initially tested in order to estimate the normality of residuals (Shapiro-Wilk test), homogeneity between variances (Levene test) and block additivity using the SPSS software (SPSS, 2008). The averages of the treatments were submitted to variance analysis (F test), using SISVAR software and then submitted to polynomial regression analysis (first and second degrees) being selected the equation with the highest coefficient of determination (statistically significant) (Ferreira, 2014).

To analyze the main components (PCA), we used $\mathrm{N}, \mathrm{P}, \mathrm{K}, \mathrm{S}, \mathrm{Ca}, \mathrm{Mg}, \mathrm{Cu}$, $\mathrm{Fe}, \mathrm{Mn}, \mathrm{Zn}, \mathrm{B}$ in the leaves and total productivity. New axes, eigenvectors (new variables) called main components (PC), were generated by linear combinations of original variables built using eigenvalues of a covariance matrix (Piovesan et al., 2008; Hair Junior et al., 2009). In order to obtain a more simple form and a more parsimonious model, we used the Kaiser criterion (2002) with eigenvectors above the unit. Analyses were performed using $\mathrm{R}$ programming language.

\section{RESULTS AND DISCUSSION}

\section{Macro and micronutrient contents in leaves}

No effect of $\mathrm{K}$ doses on leaf $\mathrm{N}$ and $\mathrm{P}$ contents in Ágata-Unaí and ÁgataMucugê was noticed. Contents ranged from 50.9 to 52.0 and 1.6 to 3.5 in
Ágata-Unaí and 42.7 to 44.5 and 2.7 to $3.2 \mathrm{~g} \mathrm{~kg}^{-1}$ of dry mass (MS) in ÁgataMucugê. $\mathrm{K}$ doses above 228.3 and 230.0 $\mathrm{kg} \mathrm{ha}^{-1} \mathrm{~K}_{2} \mathrm{O}$ reduced $\mathrm{N}$ and $\mathrm{P}$ contents in Atlantic-Unaí, respectively. All $\mathrm{N}$ and $P$ contents were within a suitable range for potato crop (Lorenzi et al., 1997), except when $\mathrm{K}_{2} \mathrm{O}$ doses up to $70.0 \mathrm{~kg}$ ha $^{-1}$ were used, making $\mathrm{P}$ content be below the suitable level (Table 1). All the values for $\mathrm{P}$ found in this study were inferior to the recommended by Pauletti \& Motta (2019).

Leaf $\mathrm{K}$ content increased linearly with $\mathrm{K}$ dose in Atlantic-Unaí. Doses above 292 and $232 \mathrm{~kg} \mathrm{ha}^{-1} \mathrm{~K}_{2} \mathrm{O}$ reduced $\mathrm{K}$ content in Ágata-Unaí and ÁgataMucugê, respectively. Doses up to 70 $\mathrm{kg} \mathrm{ha}^{-1} \mathrm{~K}_{2} \mathrm{O}$ were lower to the suitable in Atlantic-Unaí and Ágata-Mucugê, within the range proposed by Lorenzi et al. (1997) (40 - $\left.65 \mathrm{~g} \mathrm{~kg}^{-1} \mathrm{MS}\right)$ and Pauletti \& Motta (2019) (64 $\left.\mathrm{g} \mathrm{kg}^{-1} \mathrm{MS}\right)$; the other doses of all experiments were considered suitable (Table 1).

The increase of $\mathrm{K}$ doses decreased linearly the $\mathrm{Ca}$ and $\mathrm{Mg}$ contents in Ágata-Unaí. Doses above 87.5 and $156.7 \mathrm{~kg} \mathrm{ha}^{-1} \mathrm{~K}_{2} \mathrm{O}$ decreased these nutrient contents in leaves in ÁgataMucugê. In Atlantic-Unaí, doses of $\mathrm{K}_{2} \mathrm{O}$ did not influence contents of $\mathrm{Ca}$ and $\mathrm{Mg}$, which ranged from 15 to 19.7 and 6.6 to $8.9 \mathrm{~g} \mathrm{~kg}^{-1} \mathrm{MS}$, respectively (Table 1). All values found in the three experiments were suitable for $\mathrm{Ca}$ and higher to suitable for $\mathrm{Mg}$, considering all the suitable content values suggested by Lorenzi et al. (1997) and Pauletti \& Motta (2019).

$S$ contents decreased linearly with an increase of $\mathrm{K}$ dose, in Atlantic-Unaí and Ágata-Mucugê, not being influenced by the dose range in Ágata-Unaí, which presented 1.2 to $1.3 \mathrm{~g} \mathrm{~kg}^{-1} \mathrm{MS}$ (Table 1). All S contents in the three experiments were lower to the ones considered suitable by Lorenzi et al. (1997) and Pauletti \& Motta (2019).

Fernandes et al. (2011) also observed doses lower to the ones considered suitable for some potato cultivars. Thus, we highlight the importance of establishing recommendation fertilization tables for $\mathrm{S}$ for potato cultivars in different Brazilian states.

All nutrients must be in balance and in suitable amounts required by the crop, considering that high $\mathrm{K}$ doses do not guarantee adequate productivities, since $\mathrm{K}$ accumulation tends to decrease the uptake of other nutrients, such as $\mathrm{Ca}, \mathrm{Mg}, \mathrm{Fe}, \mathrm{S}$ and $\mathrm{P}$ and consequently interfere in metabolic processes of the plant. In this case, we recommend the use of foliar application (leaf spray) in order to create favorable conditions for good crop growth (Zörb et al., 2014).

$\mathrm{Zn}$ contents were not influenced by $\mathrm{K}$ doses, ranging from 65.8 to 76 ; 34.7 to 39.5 and 48.7 to $51 \mathrm{mg} \mathrm{kg}^{-1}$ MS in Atlantic-Unaí, Ágata-Unaí and Ágata-Mucugê, respectively (Table 1). The contents were suitable (Lorenzi et al., 1997; Pauletti \& Motta, 2019) for Atlantic-Unaí and Ágata-Mucugê and low comparing to the suitable value for cultivar Ágata-Unaí.

$\mathrm{Cu}$ contents increased up to dose of 376.8 and $287 \mathrm{~kg} \mathrm{ha}^{-1} \mathrm{~K}_{2} \mathrm{O}$ in Ágata-Unaí and Ágata-Mucugê, respectively. The increase of $\mathrm{K}$ doses did not influence $\mathrm{Cu}$ content in Atlantic-Unaí, ranging from 49.9 to $73.5 \mathrm{mg} \mathrm{kg}^{-1} \mathrm{MS}$ (Table 1). All contents were higher than the suitable doses recommended by Lorenzi et al. (1997) and Pauletti \& Motta (2019).

Increasing $\mathrm{K}$ doses reduced linearly B contents in all experiments (Table 1). In Ágata-Unaí and Ágata-Mucugê, B contents were suitable for potato crop. In Atlantic-Unaí, the contents were lower when compared to suitable dosage, according to Lorenzi et al. (1997) and Pauletti \& Motta (2019) recommendations.

Increase of $\mathrm{K}$ dose reduced leaf $\mathrm{Fe}$ contents in Ágata-Mucugê, increased the contents in Atlantic-Unaí up to the dose of $418.0 \mathrm{~kg} \mathrm{ha}^{-1} \mathrm{~K}_{2} \mathrm{O}$ and did not interfere in contents in Ágata-Unaí, which ranged from 211.0 to $237.6 \mathrm{mg}$ $\mathrm{kg}^{-1} \mathrm{MS}$ (Table 1). In all the experiments, the contents were higher than the suitable ones according to Lorenzi et al. (1997) and Pauletti \& Motta (2019).

Leaf contents of $\mathrm{Ca}, \mathrm{Mg}, \mathrm{Cu}$ and $\mathrm{Zn}$ in Atlantic-Unaí, $\mathrm{Mg}$ and $\mathrm{B}$ content in Ágata-Unaí and $\mathrm{Ca}$ and $\mathrm{Mg}$ in Ágata-Mucugê were higher than the ones found by Fernandes et al. (2011) and Soratto et al. (2011), and the other macro and micronutrients were inferior to the ones found by the cited 
authors, in all the experiments (Table 1). The differences between the growing regions, the applied dose and general management of the crop were also responsible for changing the response of the cultivars and nutrient uptake among the experiments.

Analyzing the low limits of the ranges of nutrient values considered suitable for Lorenzi et al. (1997) and the contents found in populations with no potassium fertilization, the authors observed that $\mathrm{K}, \mathrm{S}$ and $\mathrm{B}$ contents were $16.8 ; 38.8$ and $16.5 \%$ lower than the ones considered suitable in Atlantic-
Unaí; contents of $\mathrm{S}$ and $\mathrm{Zn}$ were 50.0 and $12.0 \%$ lower than the ones considered suitable in Ágata-Unaí and contents of $\mathrm{K}$ and $\mathrm{S}$ were 3.4 and $36 \%$ lower than the ones considered suitable in Ágata-Mucugê (Table 1).

In short, the increase of $\mathrm{K}$ dose decreased the contents of $\mathrm{S}, \mathrm{Ca}, \mathrm{Mg}$ and $\mathrm{B}$ in Atlantic-Unaí, $\mathrm{Ca}, \mathrm{Mg}, \mathrm{Zn}$ and $\mathrm{B}$ in Ágata-Unaí and $\mathrm{S}, \mathrm{Fe}$ and $\mathrm{B}$ in Ágata-Mucugê.

\section{Tuber productivity}

Cultivar Atlantic-Unaí did not show any significance by $\mathrm{F}$ test for the special class productivity. Cultivar Ágata in both locations adjusted to quadratic polynominal model for special class. The maximum doses estimated in ÁgataUnaí and Ágata-Mucugê were 235.0 and $184.0 \mathrm{~kg} \mathrm{ha}^{-1} \mathrm{~K}_{2} \mathrm{O}$, respectively, for productivity of 41.0 and $47.0 \mathrm{t} \mathrm{ha}^{-1}$ of tubers of special class (Figure 1A). The productivity of Atlantic ranged from 30.0 to 34.0 t ha $^{-1}$.

Soil constituents, source material and degree of weathering substantially reflect the effect of clay minerals on the retention or release of $\mathrm{K}$ (Zörb et al., 2014). The difference between

Table 1. Macro and micronutrient contents in potato cultivar Atlantic and Ágata cultivated in Unaí-MG and Ágata cultivated in Mucugê-BA under potassium fertilization levels. Uberlândia, UFU, 2014.

\begin{tabular}{|c|c|c|c|c|c|c|}
\hline Macronutrient & $\begin{array}{c}\text { Cultivar and } \\
\text { location }\end{array}$ & Equation & $\mathbf{R 2}$ & $\begin{array}{c}\text { Xmax } \\
\left(\mathrm{kg} \mathrm{ha}^{-1}\right)\end{array}$ & $\begin{array}{c}\text { Ymax } \\
\left(\mathrm{g} \mathrm{kg}^{-1}\right)\end{array}$ & $\begin{array}{c}\text { Suitable range } \\
\text { (Lorenzi et al., 1997) }\end{array}$ \\
\hline \multirow{3}{*}{$\mathrm{N}$} & Atlantic Unaí & $y=-0.00006 x 2+0.0274 x+43.965$ & 40.52 & 228.33 & 47.09 & \multirow{3}{*}{$40-50$} \\
\hline & Ágata Unaí & -- & - & - & - & \\
\hline & Ágata Mucugê & -- & - & - & - & \\
\hline \multirow{3}{*}{$\mathrm{P}$} & Atlantic Unaí & -- & - & - & - & \multirow{3}{*}{$2.5-5$} \\
\hline & Ágata Unaí & -- & - & - & - & \\
\hline & Ágata Mucugê & $y=-0.00001 x 2+0.0046 x+3.6415$ & 66.86 & 230.00 & 4.17 & \\
\hline \multirow{3}{*}{ K } & Atlantic Unaí & $y=0.0167 x+32.883$ & 86.93 & 450.00 & 40.39 & \multirow{3}{*}{$40-65$} \\
\hline & Ágata Unaí & $y=-0.00005 \times 2+0.0292 x+40.543$ & 91.86 & 292.00 & 44.81 & \\
\hline & Ágata Mucugê & $y=-0.00006 \times 2+0.0279 x+38.513$ & 86.35 & 232.50 & 41.76 & \\
\hline \multirow{3}{*}{$\mathrm{Ca}$} & Atlantic Unaí & -- & - & - & - & \multirow{3}{*}{$10-20$} \\
\hline & Ágata Unaí & $y=-0.005 x+15.933$ & 51.46 & 450.00 & 13.68 & \\
\hline & Ágata Mucugê & $y=-0.00004 x 2+0.007 x+20.842$ & 67.97 & 87.50 & 21.15 & \\
\hline \multirow{3}{*}{$\mathrm{Mg}$} & Atlantic Unaí & -- & - & - & - & \multirow{3}{*}{$3.5-5$} \\
\hline & Ágata Unaí & $y=-0.0035 x+8.0991$ & 74.93 & 450.00 & 6.52 & \\
\hline & Ágata Mucugê & $y=-0.00003 x 2+0.0094 x+6.833$ & 90.69 & 156.67 & 7.57 & \\
\hline \multirow{3}{*}{$\mathrm{S}$} & Atlantic Unaí & $y=-0.0006 x+1.5317$ & 53.66 & 450.00 & 1.26 & \multirow{3}{*}{$2.5-5$} \\
\hline & Ágata Unaí & -- & - & - & - & \\
\hline & Ágata Mucugê & $y=-0.0005 x+1.6217$ & 90.77 & 450.00 & 1.39 & \\
\hline \multicolumn{3}{|l|}{ Micronutrient } & \multicolumn{4}{|c|}{$\left(\mathrm{mg} \mathrm{kg}^{-1}\right)$} \\
\hline \multirow{3}{*}{$\mathrm{Cu}$} & Atlantic Unaí & -- & - & - & - & \multirow{3}{*}{$7-20$} \\
\hline & Ágata Unaí & $y=-0.00008 x 2+0.0603 x+23.135$ & 68.20 & 376.88 & 34.50 & \\
\hline & Ágata Mucugê & $y=-0.00005 \times 2+0.0287 x+17.235$ & 58.24 & 287.00 & 21.35 & \\
\hline \multirow{3}{*}{$\mathrm{Fe}$} & Atlantic Unaí & $y=-0.0008 \times 2+0.6693 x+214.72$ & 87.98 & 418.31 & 354.71 & \multirow{3}{*}{$50-100$} \\
\hline & Ágata Unaí & -- & - & - & - & \\
\hline & Ágata Mucugê & $y=-0.0741 x+216.31$ & 48.66 & 450.00 & 182.96 & \\
\hline \multirow{3}{*}{$\mathrm{Mn}$} & Atlantic Unaí & $y=0.0515 x+51.721$ & 98.35 & 450.00 & 74.89 & \multirow{3}{*}{$30-250$} \\
\hline & Ágata Unaí & $y=-0.0008 x 2+0.1651 x+103.04$ & 82.53 & 103.19 & 111.56 & \\
\hline & Ágata Mucugê & 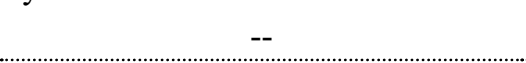 & - & - & - & \\
\hline \multirow{3}{*}{ B } & Atlantic Unaí & $y=-0.0152 x+19.773$ & 73.56 & 450.00 & 12.93 & \multirow{3}{*}{$25-50$} \\
\hline & Ágata Unaí & $y=-0.0354 x+56.94$ & 86.89 & 450.00 & 41.01 & \\
\hline & Ágata Mucugê & $y=-0.0351 x+54.45$ & 68.91 & 450.00 & 38.65 & \\
\hline
\end{tabular}

--not significant based on Tukey test, $\mathrm{p}<0.05$.

Horticultura Brasileira 38 (4) October - December, 2020 
K doses in Ágata-Unaí and ÁgataMucugê may be related to soil texture. Clay-texture soils in Unaí-MG may have favored nutrient retention to soil colloids, justifying the greater response to potassium fertilization, $21.5 \%$ higher comparing with the maximum amount estimated in Mucugê-BA.

The high yield rates of tubers in special class, where no $\mathrm{K}$ application was done (33.0 to $41.0 \mathrm{tha}^{-1}$ ), are related to good agricultural practices in these areas (pest and disease monitoring and pesticide applications at appropriate times).

Cardoso et al. (2007), Sing \& Lal (2012), Silva \& Fontes (2016) also observed positive response with $\mathrm{K}$ application in production of large and medium tubers.

The authors observed that the cultivars showed maximum yield with different $\mathrm{K}$ doses. The type of the soil and climate of each region were determinant when comparing the same cultivar. Therefore, criteria for recommendation considering the extraction rate of each cultivar and the growing region, according to physical and chemical characteristics, as well as monitoring the fertilization effects, improve the fertilizer use efficiency, provide higher accuracy in predicting dose and keep nutrients within suitable ranges (Qiu et al., 2014; Zörb et al., 2014; Fernandes et al., 2016).

As for the commercial class, Atlantic-Unaí showed productivity from 1.6 to $2.4 \mathrm{t} \mathrm{ha}^{-1}$, Ágata-Unaí responded positively up to dose of $140 \mathrm{~kg} \mathrm{ha}^{-1}$

Table 2. Average of macro and micronutrient contents in potato cultivar Atlantic and Ágata cultivated in Unaí-MG (groups 1 and 2, respectively) and Ágata cultivated in Mucugê-BA (Group 3) under potassium fertilization. Uberlândia, UFU, 2014.

\begin{tabular}{lccc}
\hline Variables & $\begin{array}{c}\text { Atlantic-Unaí } \\
\text { (group 1) }\end{array}$ & $\begin{array}{c}\text { Ágata-Unaí } \\
\text { (group 2) }\end{array}$ & $\begin{array}{c}\text { Ágata-Mucugê } \\
\text { (group 3) }\end{array}$ \\
\hline $\mathrm{N}^{*}$ & 45.7 & 51.5 & 43.4 \\
$\mathrm{P}$ & 2.8 & 3.0 & 3.9 \\
$\mathrm{~K}$ & 35.3 & 42.9 & 40.1 \\
$\mathrm{~S}$ & 1.4 & 1.3 & 1.5 \\
$\mathrm{Ca}$ & 17.4 & 15.2 & 19.9 \\
$\mathrm{Mg}$ & 9.7 & 7.5 & 6.9 \\
$\mathrm{Cu}$ & 77.2 & 29.2 & 19.3 \\
$\mathrm{Fe}$ & 284.2 & 229.2 & 204.0 \\
$\mathrm{Mn}$ & 59.6 & 105.8 & 234.3 \\
$\mathrm{Zn}$ & 77.3 & 36.6 & 49.1 \\
$\mathrm{~B}$ & 17.4 & 51.1 & 48.6 \\
Productivity & 32.9 & 39.0 & 41.4 \\
\hline
\end{tabular}

* $\mathrm{N}, \mathrm{P}, \mathrm{K}, \mathrm{Ca}, \mathrm{Mg}$ and $\mathrm{S}$ in $\mathrm{g} \mathrm{kg}^{-1} ; \mathrm{Cu}, \mathrm{Fe}, \mathrm{Mn}, \mathrm{Zn}$ and $\mathrm{B}$ in $\mathrm{mg} \mathrm{kg}^{-1}$; productivity in $\mathrm{tha}^{-1}$.

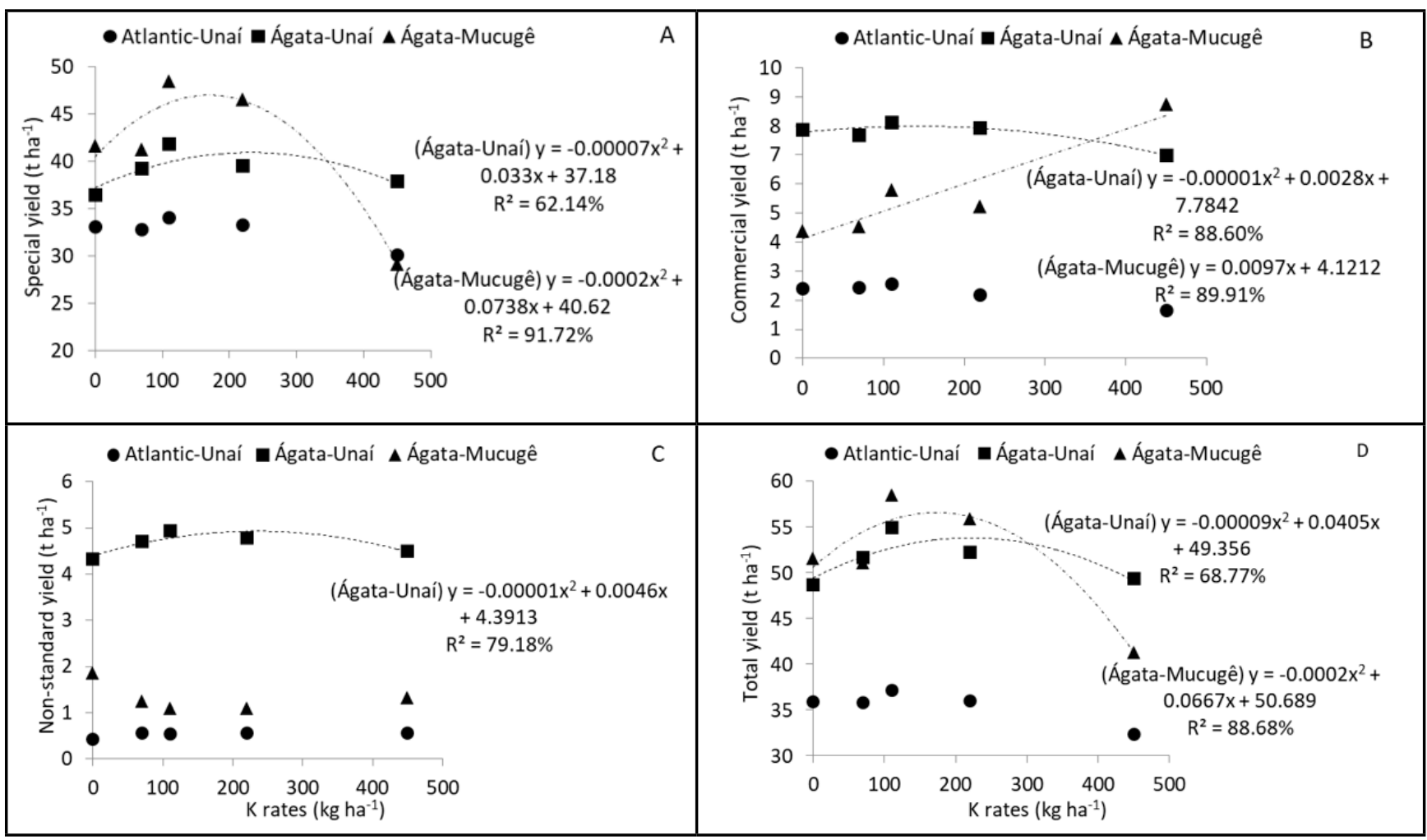

Figure 1. Yield of special class (above $45 \mathrm{~mm}$ ) (A), commercial (greater than or equal to $33 \mathrm{~mm}$ and lower than $45 \mathrm{~mm}$ ) (B) non-standard (lower than $33 \mathrm{~mm}$ ) (C) and total (D), cultivar Atlantic and Ágata cultivated in Unaí-MG and Ágata cultivated in Mucugê-BA under potassium fertilization levels. Uberlândia, UFU, 2014. 


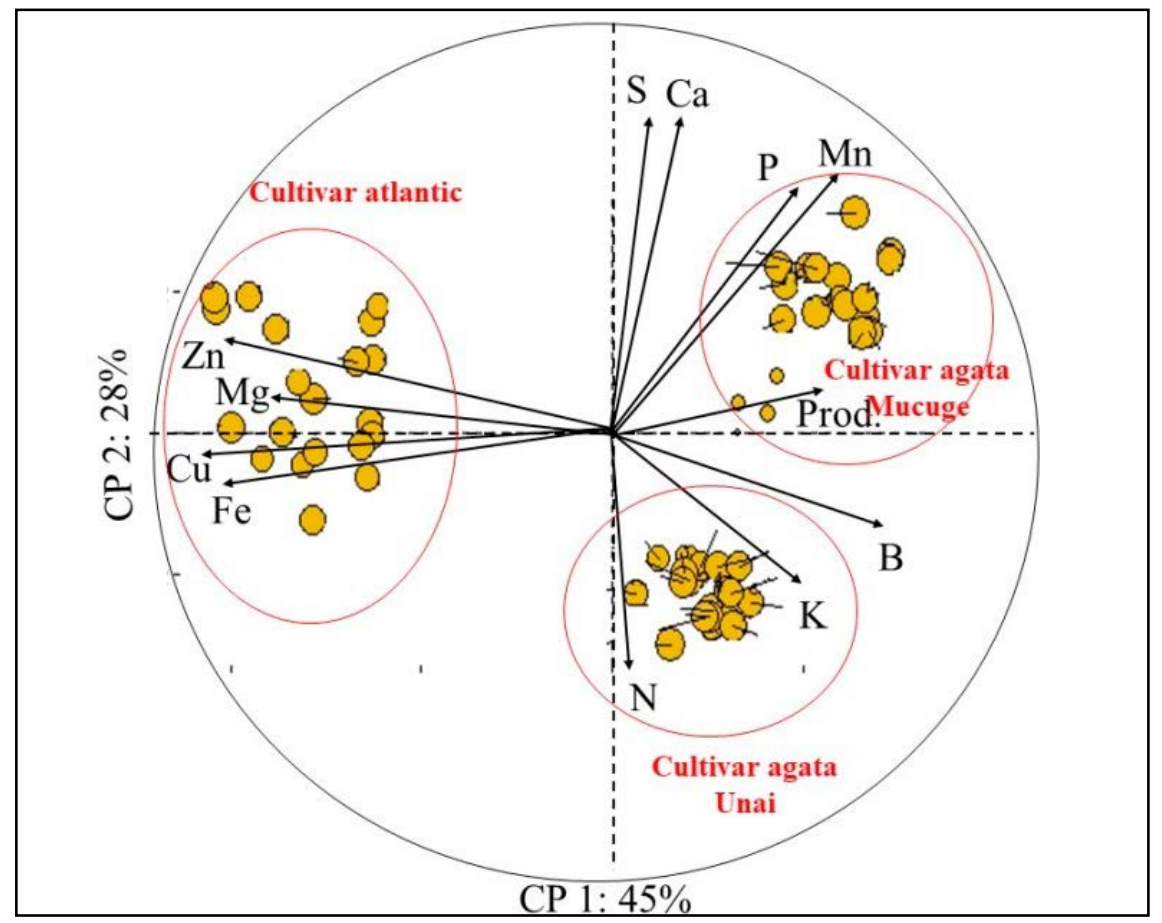

Figure 2. Principal components analysis (PCA) with the variables: macro and micronutrient contents in leaves and total yield. Uberlândia, UFU, 2014.

$\mathrm{K}_{2} \mathrm{O}\left(7.98 \mathrm{t} \mathrm{ha}^{-1}\right)$ and Ágata-Mucugê, increasing productivity up to maximum dose $\left(450 \mathrm{~kg} \mathrm{ha}^{-1} \mathrm{~K}_{2} \mathrm{O}\right)$ (Figure 1B).

For non-standard class, productivity of Atlantic-Unaí and Ágata-Mucugê ranged from 0.4 to 0.5 and 1.0 to $1.8 \mathrm{t}$ ha $^{-1}$, respectively (Figure 1C). In ÁgataUnaí, an increase in productivity up to dose of $230 \mathrm{~kg} \mathrm{ha}^{-1} \mathrm{~K}_{2} \mathrm{O}$ was noticed.

The commercial and non-standard classes have low commercial value and, therefore, doses which provide more substantial increases of the special class should be chosen. At doses higher than $184 \mathrm{~kg} \mathrm{ha}^{-1} \mathrm{~K}_{2} \mathrm{O}$ in Ágata-Mucugê, a decrease in productivity of special class and an increase of commercial class was verified, so high doses are not necessary.

$\mathrm{K}$ being monovalent presents high losses by leaching in oxisols. If $\mathrm{K}$ fertilizer application rate is excessive, nutrient losses can occur due to leaching (Qiu et al., 2014, Bhattarai \& Swarnima 2016). Literature reports that $50 \%$ of applied fertilizer can be leached below $0.6 \mathrm{~m}$ in soil profile (Rosolem \& Calonego, 2013), in a depth greater than absorption capacity by the potato root system.

Total productivity of Atlantic-Unaí ranged from 32.3 to $37 \mathrm{tha}^{-1}$. Maximum doses estimated for total productivity in Ágata-Unaí and Ágata-Mucugê were 225 and $166.7 \mathrm{~kg} \mathrm{ha}^{-1} \mathrm{~K}_{2} \mathrm{O}$, with productivity of 53.9 and $56.2 \mathrm{t} \mathrm{ha}^{-1}$, respectively (Figure 1D).

$\mathrm{K}$ content in soil in the different regions studied was good (CFSEMG, 1999), indicating that the available amount for the plants was suitable. We noticed a remarkable decrease in productivity with the dose of $450 \mathrm{~kg} \mathrm{ha}^{-1}$ $\mathrm{K}_{2} \mathrm{O}$, lower than the cropping without $\mathrm{K}$ fertilization yields. High K content in soil can cause misbalance in the ratios between bases $(\mathrm{K} / \mathrm{Ca} \mathrm{Mg}$ ) and $\mathrm{CTC}$ $(\mathrm{K} / \mathrm{T})$. This condition highlights the importance of a better proportion of $\mathrm{N}$, $\mathrm{P}$ and $\mathrm{K}$ in soil (Liu et al., 2014).

We highlight that the rates obtained in the current studies are within the ranges recommended by CFSEMG (1999), which considered expected productivity of $30 \mathrm{t} \mathrm{ha}^{-1}$. So far, the advances related to this rate ranges occurred due to several technological advances (irrigation management and pesticide use) and it is observed that the increase in productivity is more related to the adequate management of other factors which interfere in productivity than the use of high nutrient doses.

Singh \& Lal (2012) obtained an increase of about $36 \%$ applying from
150 to $225 \mathrm{~kg} \mathrm{ha}^{-1} \mathrm{~K}_{2} \mathrm{O}$, comparing with no nutrients applied. This difference found is greater than that observed in the present study, in which maximum doses obtained yields of 8.5 and $10 \%$ higher in the absence of K for Ágata-Unaí and Ágata-Mucugê, respectively. The lowest yield is related to greater-fertility soil, resulting in lower $\mathrm{K}$ use efficiency ( $\mathrm{Li}$ et al., 2015).

The negative impacts of high doses observed on productivity in ÁgataUnaí and Ágata-Mucugê may be more unfavorable if added to unnecessary costs and environmental impacts. Some studies highlight the influence of weather conditions of the regions and years of study on $\mathrm{K}$ content in soil (Zarzeck et al., 2015). The technology advance has improved the understanding of the interactions which occur in soil-plantclimatic conditions of the environment.

In relation to multivariate analysis, analyzing the principal component (PCA), a formation of two-dimensional plane and two main components was noticed (PC): $\mathrm{PC} 1$ and $\mathrm{PC} 2$, representing $73 \%$ of original information. The first $\mathrm{PC} 1$ shows $45 \%$ of variance, followed by PC2, 28\%. This result is in accordance with the criteria established by Sneath \& Sokal (1973), in which the numbers of PCs used for interpretation should explain at least $70 \%$ of total variance. The data set was divided into 3 groups which were separated into Group 1: Atlantic cultivar, Group 2: Ágata-Unai cultivar, and Group 3: Ágata-Mucugê (Figure 2). This result indicated that the variables and locations showed different performances according to productivity and nutrient availability.

Cultivar Ágata-Mucugê stood out for its greater total productivities and $\mathrm{Ca}, \mathrm{P}, \mathrm{S}$, and $\mathrm{Mn}$ content in leaves, with averages of $19.9 ; 3.9$ and $1.5 \mathrm{~g} \mathrm{~kg}^{-1}$ and $234.4 \mathrm{mg} \mathrm{kg}^{-1}$. When Ágata was cultivated in Unaí, highest contents of $\mathrm{N}, \mathrm{K}$ and $\mathrm{B}$ in plants with averages of $51.5,42.9 \mathrm{~g} \mathrm{~kg}^{-1}$ and $51.1 \mathrm{mg} \mathrm{kg}^{-1}$ could be noticed. Cultivar Atlantic showed the highest availability of micronutrients in soil, such as: $\mathrm{Zn}$ (average: $77.3 \mathrm{mg} \mathrm{kg}$ 1), $\mathrm{Cu}$ (average: $77.2 \mathrm{mg} \mathrm{kg}^{-1}$ ), and $\mathrm{Fe}$ (average: $284.2 \mathrm{mg} \mathrm{kg}^{-1}$ ), and the highest Mg macronutrient availability, average $9.7 \mathrm{~g} \mathrm{~kg}^{-1}$ (Table 2). 
We concluded that, to maximize $\mathrm{K}$ use efficiency and productivity, it is essential to observe the right dose to be used according to the response of the cultivar selected for the environment to be grown.

\section{ACKNOWLEDGEMENTS}

The authors thank to The National Council for Scientific and Technological Development (CNPq), to Coordination of Improvement of Higher Education Personnel (CAPES) and to Foundation for Research Support of Minas Gerais (FAPEMIG) for this study financing. The authors also thank to Agrícola Wehrmann (Cristalina-GO) and to Fazenda Progresso (Mucugê-BA) for supporting the experiments.

\section{REFERENCES}

BANSAL, SK; TREHAN, SP. 2011. Effect of potassium on yield and processing quality attributes of potato. Karnataka. Journal of Agricultural Sciences 24: 48-54.

BATAGLIA, OC; FURLANI, AMC; TEIXEIRA, JPF; FURLANI, PR; GALLO, JR. 1983. Métodos de análise química de plantas. Campinas: Instituto Agronômico (Boletim Técnico, 78). 48p.

BHATTARAI, B; SWARNIMA, KC. 2016. Effect of potassium on quality and yield of potato tubers - A review. International Journal of Agriculture \& Environmental Science 3: 7-12.

CARDOSO, AD; ALVARENGA, MAR; MELO, TL; VIANA, AES. 2007. Produtividade e qualidade de tubérculos de batata em função de doses e parcelamentos de nitrogênio e potássio. Ciência e Agrotecnologia 31: 1729-1736.

CFSEMG - Comissão de Fertilidade do Solo do Estado de Minas Gerais. 1999. Recomendações para o uso de corretivos e fertilizantes em Minas Gerais - $5^{\text {a }}$ aproximação. Viçosa, 359p.

EMBRAPA, Empresa Brasileira de Pesquisa Agropecuária. 1997. Análises de tecido vegetal: manual de laboratório. Documento 92, Belém (PA): Embrapa Amazônia Oriental, 1997. 32p.

EMBRAPA, Empresa Brasileira de Pesquisa Agropecuária. 2017. Manual de Métodos de Análise de Solo. 3 ed. Brasília, (DF): Embrapa, 2017, 577p

FERNANDES, AM; SORATTO, RP. 2013. Eficiência de utilização de nutrientes por cultivares de batata. Bioscience Journal 29:
91-100.

FERNANDES, AM; SORATTO, RP; EVANGELISTA, RM; JOB, ALG. 2016. Influência do fósforo na qualidade e produtividade de tubérculos de cultivares de batata de duplo propósito. Horticultura Brasileira 34: 346-355.

FERNANDES, AM; SORATTO, RP; SILVA, BL. 2011. Extração e exportação de nutrientes em cultivares de batata: I - macronutrientes. Revista Brasileira de Ciência do Solo 35: 2039-2056.

FERREIRA, DF. 2014. Sisvar: a guide for its bootstrap procedures in multiple comparisons. Ciência e Agrotecnologia 38: 109-112.

HAIR JUNIOR, JF; BLACK, WC; BABIN, BJ; ANDERSON, RE; TATHAM, RL. Análise multivariada de dados. 6.ed. Porto Alegre: Bookman. 2009. 688p.

JASIM, AH; HUSSEIN, MJ; NAYEF, MN. 2013. Effect of foliar fertilizer (high in potash) on growth and yield of seven potato cultivars (Solanum tuberosum L.). Euphrates Journal of Agriculture Science 5: 1-7.

JOB, ALG; SORATTO, RP; FERNANDES, AM; ASSUNÇÃO, NS; FERNANDES, FM; YAGI, R. 2019. Potassium fertilization for fresh market potato production in tropical soils. Agronomy Journal 111: 3351-3362.

KAISER, K; EUSTERHUES, K.; RUMPEL, C; GUGGENBERGER, G; KNABNER, KI. 2002. Stabilization of organic matter by soil minerals investigations of density and particlesize fractions from two acid forest soils. Journal of Plant Nutrition and Soil Science 165: 451-459.

LI, S; DUAN, Y; GUO, T; ZHANG, P; HE, P; JOHNSTON, A; SHCHERBAKOV, A. 2015. Potassium management in potato production in Northwest region of China. Field Crops Research 174: 48-54.

LIU, DH; WANG, L; CUI, XM; GUO, LP; JIN, HZ; HU, XY; YANG, Y. 2014. Study on dynamic change law of $\mathrm{N}, \mathrm{P}$ and $\mathrm{K}$ in Panax notoginseng plant soils with different interval year. China Journal of Chinese Materia Medica 39: 572-579.

LOPES, CA; REIS, A; LIMA, MF. 2016. Doenças e métodos de controle. In: SILVA, GO; LOPES, CA (eds). Sistema de produção de batata. Brasília: Embrapa Hortaliças. p.34-52.

LORENZI, JO; MONTEIRO, PA; MIRANDA FILHO, HS; RAIJ, B. 1997. Raízes e tubérculos. In: RAIJ, B; CANTARELLA, H; QUAGGIO, JA; FURLANI, AMC (eds). Recomendações de adubação e calagem para o Estado de São Paulo. Campinas: Instituto Agronômico. p.221-229. (Boletim técnico, 100).

NAVA, DE; DIEZ-RODRÍGUEZ, GI. 2016. Insetos e métodos de controle. In: SILVA, GO; LOPES, CA (eds). Sistema de produção de batata. Brasília: Embrapa Hortaliças. p.53-62.

PAULETTI, V; MOTTA, ACV. 2019. Manual de adubação e calagem para o estado do
Paraná. 2 ed. Curitiba: Núcleo Estadual Paraná da Sociedade brasileira de Ciência do solo (NEPAR-SCS). 289p.

PERVEZ, MA; AYYUB, MICM; SHABEEN, MR; NOOR, MA. 2013. Determination of physiomorphological characteristics of potato crop regulated by potassium management. Pakistan Journal of Agricultural Sciences 4: 611-615.

PIOVESAN, P; ARAÚJO, LB; DEANDDIAS, CTS. 2008. Validação cruzada com correção de autovalores e regressão isotônica nos modelos de efeitos principais aditivos e interação multiplicativa. Ciência Rural 39: 1018-1023.

QIU, S; XIE, J; ZHAO, S; XU, X; HOU, Y; WANG, X; ZHOU, W; HE, P; JOHNSTON, AM; CHRISTIE, P; JIN, J. 2014. Long-term effects of potassium fertilization on yield, efficiency, and soil fertility status in a rain-fed maize system in northeast China. Field Crops Research 163: 1-9.

ROSOLEM, CA; CALONEGO, JC. 2013. Phosphorus and potassium budget in the soilplant system in crop rotations under no-till. Soil \& Tillage Research 126: 127-133.

SANDAÑA, P; ORENA, S; ROJAS, JS ; KALAZICH, J; URIBE, M. 2020. Critical value of soil potassium for potato crops in volcanic soils. Journal of Soil Science and Plant Nutrition 20: 1171-1177.

SILVA, GO. 2016. Manejo de plantas daninhas. In: SILVA, GO; LOPES, CA (eds). Sistema de produção de batata. Brasília: Embrapa Hortaliças. p.34.

SILVA, HRF; FONTES, PCR. 2016. Adubação potássica e seu efeito residual sobre a produtividade e a qualidade de tubérculos de batata. Pesquisa Agropecuária Brasileira 51: 842-848.

SINGH, SK; LAL, SS. 2012. Effect of potassium nutrition on potato yield, quality and nutrient use efficiency under varied levels of nitrogen application. Potato Journal 39: 155-165.

SNEATH, PH; SOKAL, RR. 1973. Numerical taxonomy: the principles and practice of numerical classification. San Francisco: WH Freeman. 573p.

SPSS v. 17.00 SPSS. Chicago, Illinois, 2008. CD-ROM.

ZARZECK, K; GUGAE, M; MYSTKOWSK, I; SIKORSK, A; BARANOWSK, A. 2015. The effect of agrotechnical factors on the potassium content and its removal by potato tubers. Journal of Ecological Engineering 16: $180-184$

ZELELEW, DZ; LAL, S; KIDANE, TT; GHEBRESLASSI, BM. 2016. Effect of potassium levels on growth and productivity of potato varieties. American Journal of Plant Sciences 7: 1629-1638.

ZÖRB, C; SENBAYRAM, M; PEITER, E. 2014. Potassium in agriculture - Status and perspectives. Journal of Plant Physiology 171: 656-669. 